\title{
EFL in Public Schools in Mexico: Dancing Around the Ring?
}

\section{Inglés en las escuelas públicas en México: ¿bailando en el cuadrilátero?*}

Nora M. Basurto Santos

nbasurto@uv.mx

\section{Jolene R. Gregory Weathers}

ohohmexico@hotmail.com

Universidad Veracruzana, Veracruz, Mexico

The teaching and learning of English as a foreign language has a long tradition within the Mexican public education system. Unfortunately, this endeavor has been unsuccessful for the most part throughout the country. In this paper, we share and compare the results of two studies, ten years apart, whose data collections were carried out in very similar contexts. Both studies looked at what is happening in practice from the teachers' perspectives. Class observation, interviews, and official documents were important sources of information. We conclude that even though there has been ten years between these two studies there seem to be no changes that could enhance the teaching and learning of English as a foreign language in public schools.

Key words: English as a foreign language, Mexico, public schools.

La enseñanza y el aprendizaje del inglés como lengua extranjera tienen una larga tradición en el Sistema de Educación Pública de México. Infortunadamente, esta actividad no ha sido exitosa la mayor

* $\quad$ Received: July 1, 2015. Accepted: December 4, 2015.

How to cite this article (APA 6th ed.):

Basurto Santos, N. M., \& Gregory Weathers, J. R. (2016). EFL in public schools in Mexico: Dancing around the ring? $H O W, 23(1), 68-84$. http://dx.doi.org/10.19183/how.23.1.297.

This article is licensed under a Creative Commons Attribution-NonCommercial-NoDerivatives 4.0 International License. License Deed can be consulted at http://creativecommons.org/licenses/by-nc-nd/4.0/. 
parte del tiempo en todo el país. En este artículo compartimos y comparamos los resultados de dos estudios que se llevaron a cabo en contextos muy similares pero con un período de 10 años entre ellos en cuanto a la recolección de los datos. Ambos estudios se concentraron en descubrir qué sucede en la práctica de la enseñanza del inglés desde la perspectiva de los profesores. Observaciones de clases, entrevistas y documentos oficiales fueron importantes fuentes de información. Se pudo concluir que, a pesar de que han pasado diez años entre estos dos estudios, pareciera que no ha habido cambios que pudieran contribuir a una mejor enseñanza-aprendizaje del inglés en las escuelas públicas.

Palabras clave: escuelas públicas, inglés como lengua extranjera, México.

\section{Introduction}

Although English as a foreign language (EFL) has been present in Mexican public education for many years, a lot of problems have prevailed (see Basurto Santos, 2010). However, since 1993, when secondary education became officially obligatory, it seems that the problems in EFL classrooms have increased. It is not difficult to assume that if there were longstanding problems in the teaching and learning of EFL in the public sector before 1993, these seem to have grown due to the fact that the government has committed itself to providing EFL instruction to all Mexican children. To mention one example, if before 1993 it was common to find around 40 students in EFL classrooms which limited foreign language practice, then with the increase of enrollment, providing adequate practice could be even more difficult.

In this paper, we will present and discuss two studies carried out in public secondary schools in the same area in Mexico. It is worth pointing out that these two studies were conducted at different times. The data for the first study were collected by Nora between 2003 and 2005 while the data for the second study were obtained by Jolene in 2015. That is, there is more than a 10-year time difference between these two studies. What struck us as interesting was the fact that even though the primary researcher of the second study was completely unaware of the results of the first study when we came together to talk and discuss Jolene's findings, Nora realized that these were very similar to her study carried out at least ten years before. Therefore, we would like to share the changes or lack thereof during the last ten years regarding EFL in public schools in Mexico. In order to do this, we will begin by providing a review of relevant literature. Both studies adopted very similar approaches to research which we will present in the Method section. Having done this, we will share the findings and implications to finally draw some conclusions.

\section{Literature Review}

Policy and planning are commonly interchanged in literature, however Baldauf (2005) describes policy as "the plan" and planning as "the implementation of the plan" (p. 958). This 
distinction is essential in understanding that the plan and the implementation are separate and, as such, an established policy may or may not be implemented as intended. Therefore, there is increasing research being done into how policies are being interpreted and negotiated, reflecting local limitations and possibilities or policies that focus on classroom teachers as central agents of implementation (Basurto Santos, 2010; Li, 1998; Nunan, 2003; Silver \& Skuja Steele, 2005; Wedell, 2008; Zappa-Hollman, 2007). Therefore, a basic recognition of language policy and planning changes in the Mexican education system in 1993 can provide a key understanding as to why EFL instruction in Mexico has not been successful.

In the case of EFL in public secondary schools in Mexico, the policy changed from a focus on grammar and translation to adopting a communicative language teaching (CLT) approach (Secretaría de Educación Pública [SEP], 2006). However, in 2001 an exploratory study revealed that little change had occurred in practice and therefore learning objectives were not achieved (SEP, 2006). In a quantitative study in Mexico City, González Robles, Vivaldo Lima, and Castillo Morales (2004) also found that $95.9 \%$ of students who had attended public schools failed a linguistic competence test upon entering higher education. This seems to demonstrate a gap between rhetoric and reality (Nunan, 2003). The lack of change or improvements in educational practices, more often than not, has been attributed to teachers' perceptions of the feasibility of innovation in a particular context which are crucial in determining the ultimate success or failure of that innovation (Kelly; Markee as cited in Li, 1998). In addition, the meso (institutional) and macro (school system) contexts have been found to have a significant influence on teacher practices, both enabling and constraining teachers (Opfer \& Pedder, 2011). Therefore, changes in teachers' "declarative knowledge or espoused knowledge may not lead to changes in their practices, due to a range of personal or system influences" (Askell-Williams \& Murray-Harvey, 2013, p. 204). González (2009) adds that a certain methodology may not be implemented as designed because "language policies often ignore their connection to actual language learning because they do not have a basis in reality, and thus, remain as good intentions on paper" (p. 186).

It has been highlighted that the success of the implementation of policy is influenced by many aspects. For example, Zappa-Hollman (2007) in a study carried out in Argentina, identified the following aspects: large classes (35 students per class), lack of adequate teaching and learning resources (e.g., textbooks, authentic materials, audiovisual materials, and equipment), and reduced length and frequency of EFL teaching periods. As a result of all the problems encountered in their classrooms, teachers acknowledged that they concentrated more on literacy-based activities rather than on developing the learners' spoken communicative ability or developing the four skills as required by the program (Basurto Santos, 2010). More recently, researchers conducted a study with Colombian EFL teachers and identified the following aspects: number of students per group, time aspects, human and material resources, physical conditions of schools' classrooms, the role of administrators, 
opportunities for professional development, meetings and curricular planning in the area, and the status of English in the institution, and methodology (Cárdenas Ramos \& Hernández Gaviria, 2012).

How these constraints are addressed has been identified as key in improving teaching and learning. In their study, Haque and Cray (2007) concluded that offering teachers ad hoc solutions (workshops, new teaching materials and resources, or even new versions of the curricula) to deal with the constraints posed by their contextual realities was to provide them with limited assistance. Similar results were found in other studies (Baldauf \& Kaplan, 2005; Prapaisit de Segovia \& Hardison, 2009). In her study, conducted in Argentina, Zappa-Hollman (2007) concluded that to provide quality in EFL instruction, the state policy should be re-examined in order to determine more plausible objectives considering the actual teaching context. It is important to keep in mind that as policy is being re-examined, the EFL teachers should play a major role in reform as they are an "untapped resource in the decision making process" (Prapaisit de Segovia \& Hardison, 2009, p. 14). Zappa-Hollman also proposes that teachers should be equipped with adequate professional training and resources identified as necessary for their contexts. Otherwise, access to quality public education will not go beyond policy rhetoric.

\section{Method}

The main aim of both research projects described in this paper was to develop a picture of the EFL teachers' experiences in public secondary school classrooms from their own perspectives and the effect of their experiences on learning outcomes. Therefore, a qualitative research approach was adopted for both studies as this type of research has the goal of "understanding the underlying reasons" for what we observe, which is necessary in order to lead to an "understanding of what needs to be done to change things" (Denzin \& Lincoln, 2003, pp. 4-5; Gillham, 2000). Qualitative research is ideal for this situation because as Bourgeault (2012) states:

Qualitative research has improved our understanding of certain dimensions of individuals, groups, organizations and societies such as how we organize our social relationships, communicate with each other, and make sense of the situation in which we find ourselves. (p. 2)

Both studies were conducted as case studies. They were descriptive in nature as they were undertaken to present a detailed account of the phenomenon under study (Merriam, 2009). In addition, they were instrumental case studies since they were carried out mainly to provide insight into an issue or to draw a generalization because case study "provides evidence of uniqueness and commonality" (Stake, 1995, pp. 3-4).

Case study research has been criticized as being limited in its ability to make generalizations based on a single case. However, research in the interpretive or constructivist 
paradigm has recognized the concept of generalizability which aligns with qualitative inquiry (Gomm, Hammersley, \& Foster, 2000). Stake (2003) argues for the value of case study research stating that:

It is reasonable to conclude that one of the more effective means of adding to understanding for all readers will be by approximating, through the words and illustrations of our reports, the natural experiences acquired in ordinary personal involvement. (p. 19)

Therefore, we desire to share the findings derived from these studies with the hope that they will resonate in the broader context of TESOL (Teaching English to Speakers of Other Languages). In summary, both studies were instrumental, descriptive case studies carried out in an attempt to better understand teachers' experiences in Mexican public secondary EFL classrooms from their own perspective. From this, we hope to be able to identify some key factors that may be limiting the learning outcomes.

\section{Context}

In both studies, contact with each context was originally made through personal contacts of the researchers. This is because personal contact is very important in Mexico, and the most productive way of sampling tends to be a combination of snowball sampling, where one person puts you in touch with another, together with opportunistic or emergent sampling when fieldwork is involved (Basurto Santos, 2010). However, because of the variety of contexts of each of the schools in our studies, we feel that they are a fair representation of secondary schools in our area and in the rest of the country.

The fieldwork for the first study was carried out in two phases during 2004 and 2005. The fieldwork was conducted in three secondary schools in a city in southeastern Mexico. Although the schools are located in distinct contexts in the city, they have a common organizational structure: two shifts (morning and afternoon), same number of groups (18, three for each grade), and more or less same number of students in each group, between 40 and 47.

One of the schools is situated on the border of a highly desirable neighborhood. However, not all the students that attend the school live in the area, but according to the academic coordinator most students are from middle class families. This is important to bear in mind since students in this school are very likely to have had previous EFL knowledge. The second secondary school is located close to two of the main arteries that run along the city near downtown. The population in this area ranges from low-middle class to upper-middle class. Comparatively, this is a bigger school with more spacious classrooms and more open spaces for the students to play in. Finally, the third one is situated in an area of the city where most people are low-middle class or poor. The socio-economic background of the students and the location of the school have an important bearing on the teaching/learning of EFL. 
For example, many students who attend this school have to study and work simultaneously to support their home living expenses. This has implications for learning in general and for EFL in particular.

The fieldwork for the second study was carried out in 2015 with teachers that worked in a public secondary school in a small town located approximately 40 minutes from the city where the first study was carried out. This town has only one secondary school, where over 500 students attend in the morning shift. The students had 50-minute English classes three times a week. There were five groups of approximately 35 to 40 students in each group, for each of the three grades.

The classrooms contain desks and a whiteboard. There is one CD player available for all the teachers to share, but the teachers reported that it did not always work. The school also has one projector available for all the teachers to use. There is limited space in the classroom, approximately 1.5 feet between each row of desks with a three-foot wide area at the front of the classroom. The students each have a copy of the textbook: Cool Time by Richmond publishers for first grade students, and English Corner by Macmillan Publishers for second and third grade students. The teachers do not have their own classroom, but change classrooms for each group. Also, the teachers do not have any personal workspace provided in the school.

\section{Participants}

In the first study the teachers' ages ranged from 24 to 55 . All had completed a BA in EFL at Universidad Veracruzana. Two of them had also studied the Especialización (Diploma) in EFL teaching many years after completing their BAs. Their experience in teaching on those educational levels ranged from three years to over 30 years. All of them were female. Two of the teachers in the secondary schools were teaching both shifts. The rest of the teachers were also teaching English in other institutions. Most of them were teaching 40 hours per week.

In the school where the second study was conducted, there were five teachers who taught English. One teacher taught seven groups, another teacher taught five groups, and the remaining three teachers taught only one group each. The study involved three teachers from the same school. Their pseudonyms are Agnes, Fernando, and Javier.

Agnes is a 36-year-old female. She has a BA in teaching English and a master's in applied linguistics. She has worked in private and public universities, secondary schools, and kindergartens. She had 14 years of teaching experience at the time of the study. In this particular school she had taught for two years. She taught first and third grades in the school where the study was carried out during 2014 and 2015, and had a total of 280 students divided into seven groups. 
Fernando is 43 years old. He has a BA in teaching English. He had two years of teaching experience, one of those years at the school where the study was conducted. He taught five second grade groups during 2014 and 2015 with a total of 210 students.

Javier is 32 years old. He has a bachelor's degree in civil engineering and another in foreign languages. He had been teaching for one and a half years at the school where the study was conducted. He taught one third grade group during 2014 and 2015 that had 36 students in attendance on the day of the class observation. He also taught mathematics at the school.

\section{Data Collection}

The data collection involved multiple sources of information in order to generate a more comprehensive perspective. It included classroom observations (in the case of the second study), interviews, and document analysis. Having multiple sources of data collection allowed us to validate and crosscheck findings (Patton, 2002).

\section{Instruments}

Classroom observations. For the classroom observations in Jolene's study, a naturalistic observation approach was used since there were no clearly identified categories and coding worked out in advance (Cohen, Manion, \& Morrison, 2013). The objective of the observation was to obtain a descriptive observation (Flick, 2014) regarding the physical setting, the human setting, the interactional setting, and the program setting.

A classroom observation sheet and expanded field notes were designed and used to collect data. The classroom observation sheet was adapted from the William and Mary classroom observation scales (Van'Tassel-Baska et al., 2003) and from research based classroom strategies in Fox (2014).

Interviews. In both studies, semi-structured interviews were used because they allow participants to "discuss their interpretations of the world in which they live, and to express how they regard situations from their own point of view" (Cohen et al., 2013, p. 409). Therefore, as Brinkman and Kvale (2009) affirm, an interview allows the researcher to obtain information that goes beyond what she/he is expecting to discover. Also, Cohen et al. (2013) mention that interviews identify a range of factors in human behavior such as emotions, interpersonal influences, unconscious needs, preferences, values, attitudes, and beliefs.

In order to do so, a brief interview guide was used with open questions to initiate a topic and then the teacher was probed to share more information in areas of interest (Rubin \& Rubin, 1995). The interviews were also carried out in Spanish at the teachers' requests. The interviews were recorded and later transcribed verbatim using a three-column template for all 
the transcripts (Basurto Santos, 2010). The researchers then translated the extracts from the interviews appearing in this text.

Document analysis. An analysis of relevant documents provides an understanding of the historical origins which "explain current structures, relationships and behaviors in the context of recent and longer term trends" (Cohen et al., 2013, p. 248). However, given that documentary sources have been criticized for failing to engage with the classroom and the interface between teachers and learners (Goodson, 1988); the affirmations made in the documents were compared and contrasted with the data that emerged from the classroom observations and interviews and vice versa. Therefore, the study of documents is thus of importance for qualitative researchers who wish to explore multiple and conflicting voices, differing and interacting interpretations (Hodder, 2000; Prior, 2003).

The documents that were analyzed in the first study included: Secondary and Preparatory EFL syllabi, EFL textbooks, World Wide Web pages: SEP, SEC (Secretaría de Educación y Cultura), CENEVAL (Centro Nacional de Evaluación para la Educación Superior), national and local newspapers, and EFL teachers' documents such as official timetables and students' attendance lists. The second study included an analysis of SEP documents including syllabi; guides regarding the Consejo Técnico (Technical Council), school supervision, and teacher hiring and contracts; and the catalog of professional development. In addition, the second study included an analysis of the undergraduate program study plans for the three universities which the teachers attended.

\section{Data Analysis}

The process of analysis in qualitative research is a complex and a laborious one. The challenge of qualitative analysis, Patton (2002) argues, is to make sense of an impressive amount of data. In both studies this was carried out manually. The approach adopted for the initial coding of the interviews was mainly the one proposed by Richards (2003). That is, each data set was coded individually and then compared and consolidated with the coding of the other data sets. The categories that emerged were evaluated based on the characteristics found in literature in order to gain greater understanding of the factors influencing learning outcomes.

\section{Findings}

In this section, we present and discuss some of the categories that emerged from the process of data analysis. We decided to focus on those themes that we found were remarkably similar in both studies even though there is a gap of over ten years between the processes of data collection and analysis. 


\section{Typical EFL Lessons in Mexican Public Schools}

It was really surprising to find out that what was described by participants in Nora's study was very similar to that observed by Jolene in EFL lessons. Nora's study (Basurto Santos, 2010, p. 135) described a typical day as the following:

The bell rings. The EFL teachers arrive at the classroom a few minutes later. They go straight to their desk which is on a wooden platform while they greet the class in English: "good morning" or "good afternoon." From the elevated platform, teachers, most of the time, can keep an eye on the 40 or 45 students sitting in rows. The students, on the other hand, cannot see, let alone work with, their classmates except for the ones next to them on each side. The students' chair-desks are hardly ever moved around since there is not enough room. Lessons start with the calling of the roll. By this time around 10 minutes have been used up. This is immediately followed by one of two activities: teachers either put a lámina (wall chart) on the board for students to copy its contents in their notebooks or teachers explain a grammar point and then ask students to do exercises from page $\mathrm{x}$ to $\mathrm{z}$ : "now you do from page 90 to 97 ." Twenty or 25 minutes have passed. Homework checking begins. One at a time, students are called to approach the teachers' desk while the rest of the group remains on the set activity. The teachers tick each page where students have written the tasks assigned and sign the final page. According to the students, EFL teachers hardly ever have the time to write any feedback or point out if there is something wrong. Nor do they explain why anything is wrong. The teachers' signatures are proof that students have done the assignments and testimony of one the forms of student "participations" that are part of their grades. While this activity is being carried out, the teachers are also constantly silencing the students or reminding them to keep on the activity assigned. If not, they threaten, points can be deducted from grades. Thirty-five minutes have gone by. The next activity is class participation. Teachers ask at random—using their student lists—or if students are "lucky", the exercises are "chain" answered thus allowing the students to predict which question they have to answer. If the answer is correct, they get an extra point for class participation. Fifty minutes have passed. The lesson is over. The next class will follow a very similar pattern.

The following field note from Jolene's research diary shows that the CLT approach does not seem to be implemented in the classrooms:

Oral practice is basically reading out loud not actual production; no English is used to communicate within the classroom (Field note 5, 2015).

The description from Nora's study and the observation from Jolene's study seem to confirm that little change in practice has occurred in EFL teaching as identified by the SEP (2006).

In 2004 and 2005, EFL teachers and school authorities in Nora's study, mentioned that the lack of change was largely due to the mismatch between what the system states should happen and what in reality could be done due to contextual constraints, an aspect which those responsible for designing and planning EFL curricula did not seem to take into consideration. 
The following quote from one of the school authorities expresses a common frustration that already existed over ten years ago:

There is no congruity...I'm telling you this because of the poor interest they've shown to improve, to update, to make the EFL teaching more relevant, come on! It's supposed that as they give you the topics then the teacher has to make it relevant, YEAH RIGHT but as long as they provided the necessary conditions AS WELL! Imagine, I'm complaining and I live in a city, what would teachers in rural areas think if they have no support? (Academic co-coordinator)

The demands imposed by the system on the EFL teachers, given the characteristics of the Mexican context, made the academic co-coordinator suspect that the people in charge of the EFL planning and policy did not consider the realities of teaching EFL. It seems that since she was a former EFL teacher this made her aware that there was a mismatch between the rhetoric of the educational authorities and what is feasible and realistic in the state secondary school. Interestingly, she acknowledged that it was unfair of the system to ask EFL teachers to do what is stipulated in the program since the people in charge of EFL planning did not provide the sort of working conditions that are considered indispensable for the efficient delivery of the syllabus contents.

In the Mexican context both syllabi for EFL teaching and learning in secondary education stipulate that students are expected to be the "main actors of the educational process." Therefore, all learning contents have to be "adapted," as far as possible, to "their needs and real interests" so that they are motivated in taking an active role in their own learning. For this to be put into practice the EFL teachers' role is conceived as "facilitators of learning and organizers of class activities" (Basurto Santos, 2010, p. 116). They are also expected to promote communicative situations and encourage students to work, when necessary, independently from teachers. All these attitudes toward teaching and learning stipulated in the Mexican EFL policy are undisputedly desired conditions for teaching and learning in EFL classrooms. However, in reality, teachers in both studies said that time, the number of students in each group, the reduced space of their classrooms, and the lack of necessary teaching resources have all contributed to creating the opposite learning conditions to what is stipulated in the official documents.

\section{Time}

The syllabus (SEP, 2006) states that students receive 50 minutes of instruction three times a week during the 40 weeks of the school term. However, most teachers have expressed that time for EFL instruction should be increased if real change is to be achieved. For example, in Nora’s study, Lolita stated: "I think that English lessons should be one hour every day."

Similarly, from Jolene’s study, Javier said that: “[English] classes in Secondary School should be, at least five hours per week." In addition, teachers report that the actual instruction time is 
reduced. In the first study, Gisela shared that: "[class] is 50 minutes [long], which is reduced to 30 when you have to check homework, you have to check attendance and etc., etc., etc."

Agnes, one of the participants in the second study, echoed this concern about the instruction time available in classrooms:

It is not true [that we] have a 50 -minute class. [It is less time] . . like 40 minutes because you enter the classroom, take out your things, call the roll, ask the students to behave, etc., [and at least] 10 minutes have already passed.

Another challenge that was previously mentioned was in regard to oral practice and the time available for instruction and practice in the classroom. Fernando stated:

But here I have 40 students and they are too many, bijole... sometimes I try to practice with a few students. I say " now, this row, you are going to practice today and next class other classmates will be given the opportunity to practice speaking in English ... I just can't manage with all the students I have in only one group, no it's impossible.

The teachers indicated that the actual instruction and practice time is significantly less than that indicated in the syllabus. In addition, they feel that in order to obtain the learning objectives in the syllabus it is necessary to increase the time allocated for English instruction. This echoes Gillies and Jester Quijada (2008), who indicate that time is a determining factor between accessing a language and learning a language.

It is worth mentioning that EFL teachers in both studies did not only express their concern about the limited time for English instruction but showed that they had been thinking or trying to find some solutions to improve their students' EFL learning. For example, Fernando mentioned to Jolene that he was planning to implement a strategy to hopefully reduce the time used for taking attendance and try to make more room for oral practice in his lessons.

\section{Class Size}

Research has shown that the ideal number of students in a given classroom has proved to be a controversial issue since more often than not budgetary considerations have been prioritized over the teachers' or the students' needs (Glass, Cahen, Lee Smith, \& Filby, 1982). Furthermore, it has also been shown that the number of students in a class has an impact on the quality of teaching and learning and especially on learners' attainment (Galton, Gray, \& Rudduck, 2003). Research on EFL communicative teaching contexts, especially in developing countries, has shown that overcrowded groups or classes that are too large represent a challenging reality for EFL teachers (Sarwar, 2001), especially when these contexts lack adequate teaching and learning resources (Peng, 2007). The following quote is fairly representative of what teachers in Nora's study stated: 
I have 48-52 students [per group]. We have asked to have groups with no more than 40 students but they keep on enrolling and enrolling ... I'd like to have smaller groups. Our classrooms are small and uncomfortable, we cannot do any group dynamics because the time we take trying to move the chairs around or to find the room to do something different, that takes up almost all the class-time, there is NO space to do small group activities, different dynamics instead of teacher fronted or students sitting in rows. (MY)

Over ten years later, EFL teachers find themselves struggling with the same situation regarding the number of students they have in each group. The following quote by a teacher in Jolene's study demonstrates this:

It would be perfect if the groups had 25 students ... maybe even 30 students but no more. (Javier)

The teachers in Jolene's study also identified other areas where group size inhibited their teaching, such as error correction and adequately checking homework.

\section{Class Mix}

A further important issue aggravating the situation of EFL teaching and learning within the public school setting is the lack of students' differentiation according to their EFL knowledge. This is something that all participants, in Nora's research, regarded as one of the biggest problems for both teachers and students alike. Yolanda, a secondary teacher, highlighted this issue in the following extract:

There are many different [students' EFL] levels within the same group. There are learners who have had the opportunity to take or are taking English courses in other institutions and well you can see the HUGE difference between those learners and the ones who haven't had that opportunity. This represents a CHALLENGE for me because I KNOW that they ALREADY know what I'm teaching.

This issue has recently been aggravated by the fact that since 2003, EFL programs have been implemented in some elementary schools. Therefore, the teachers stated that the program for secondary schools is now based on prior knowledge attained in the elementary school EFL program. However, in the study carried out by Jolene, Agnes states:

Supposedly, the students have already had contact with English since elementary school. But that is only on paper, not in practice. In some schools the parents come together and pay for a teacher, but in [this town] that doesn't happen.

This lack of student streaming has had, for over a decade, a negative impact on the learning process as Javier highlights:

The fact is that students sometimes do not have the preparation that they should have had for the level they are in.

Having excessively large groups where EFL teachers have to deal with students whose EFL level may differ a great deal represents a challenge to teachers who do not have the freedom to group the students according to their EFL knowledge. 


\section{Limited Resources}

Teachers in both studies also identified the lack of resources as a key factor in preventing them from implementing the syllabus set by the educational authorities in Mexico. In 2004, Gisela, a secondary teacher, could articulate very clearly how she was limited in the activities she could carry out in the EFL classroom due to the lack of teaching materials other than the textbook provided by the SEP:

The SEP sends different cassettes and videos for ALL other subjects but for ENGLISH there is NOTHING, I tell you because I have asked “what's new for English?” and they say “no, well, there's nothing" because even to rest from the routine of the classroom you could say "ok, today we are going to watch a movie" or do something different, no? But there is NOTHING, NOTHING. BUT I Think that the school principal is not to blame but rather it is the SEP since they are in charge of sending the MATERIALS. There is a LOT for Biology, there is a lot for HISTORY, there are many things, there are tapes for other subjects but not for ENGLISH, there is NOTHING.

At that time, Nadia, another secondary school teacher, also complained about all the limitations that she was facing as an EFL teacher in her particular teaching context:

Well, [the working conditions for an EFL teacher in secondary education] are not the adequate because for starters, for example, the SOCKETS in the classrooms DO NOT work, then if we want to work with the tape recorder we have to buy BATTERIES and that's very EXPENSIVE to be ALIWAYS buying batteries then to be honest I DON'T use the tape recorder because of that. We DO NOT have a place, a locker where to keep our materials, NOTHING. We have to be CARRYING all our materials then that's heavy I mean the entire teaching and on top of that CARRYING well, NO!

Gisela's and Nadia's complaints, over a decade ago, are echoed by the teachers in Jolene's study. A common complaint is found in Agnes' words:

Also the resources in the school...that is also difficult because if we are saying that there should be a variety of stimuli, well that is not accomplished, that is an ideal situation. But we don't have a projector in each classroom ... or computers. They just installed internet but they only allow you to connect for 30 minutes. The CD player doesn't work.

This ongoing frustrating teaching situation makes Javier conclude:

So it is more practical to teach them grammar. Not so much because I want to, but because sometimes given the conditions it is more feasible.

All these difficult situations that the teachers mentioned above seem to highlight the impossibility of making EFL teaching and learning more in accord with what is expected of them as stated in the official syllabus.

\section{Conclusions}

As we have "heard," from the main actors in EFL teaching, that is, the teachers, teaching or trying to teach English as a foreign language in public schools is encumbered by the 
conditions found in schools: time, class size, class mix, and available resources. Although the results presented in this paper come from two studies that were carried out in different years, with a 10-year gap between them, there seems to be no significant improvement in these conditions. We conclude that no matter what EFL teachers try to do to improve their students' learning experience if they are not provided with the working conditions deemed necessary to enhance the teaching and learning of EFL in the public sector the unsuccessful situation will prevail, echoing Cárdenas Ramos and Hernández Gaviria (2012), Haque and Cray (2007), and Zappa-Hollman (2007).

Teachers have good ideas as to what needs to be done to improve the quality of EFL in public secondary schools. In order to take action that positively impacts teaching and learning, EFL teachers, as experts in the realities of the classrooms, need to be taken into account when educational changes are planned. Also, school authorities must commit to take action and change those aspects which are known to limit teaching and learning. Otherwise, EFL teaching and learning in the public sector will continue to imitate that of two boxers who are in the ring to fight but do not actually attempt to land any blows but rather just dance around the ring.

\section{References}

Askell-Williams, H., \& Murray-Harvey, R. (2013). Did that professional education about mental health promotion make any difference? Early childhood educators' reflections upon changes in their knowledge and practices. Australian Journal of Guidance and Counselling, 23(2), 201-221. http://dx.doi.org/10.1017/jgc.2013.19.

Baldauf, R. B. (2005). Language planning and policy research: An overview. In E. Hinkel (Ed.), Handbook of research in second language teaching and learning (pp. 957-970). London, UK: Routledge.

Baldauf, R. B., \& Kaplan, R. B. (2005). Language-in-education policy and planning. In E. Hinkel (Ed.), Handbook of research in second language teaching and learning (pp. 1013-1034). London, UK: Routledge.

Basurto Santos, N. M. (2010). Transition in EFL from secondary to preparatory in Mexican state schools: Participant perspectives. Xalapa, MX: Universidad Veracruzana.

Bourgeault, I. L. (2012). Critical issues in the funding of qualitative research. Journal of Ethnographic and Qualitative Research, 7(1), 1-7.

Brinkmann, S., \& Kvale, S. (2009). InterViews: Learning the craft of qualitative research interviewing. Thousand Oaks, CA: Sage.

Cárdenas Ramos, R., \& Hernández Gaviria, F. (2012). Opportunity to teach and learn standards: Colombian teachers' perspectives. PROFILE Issues in Teachers' Professional Development, 14(2), 77-94.

Cohen, L., Manion, L., \& Morrison, K. (2013). Research methods in education (7th ed.). London, UK: Routledge Falmer.

Denzin, N. K., \& Lincoln, Y. S. (Eds.). (2003). The landscape of qualitative research: Theories and issues (2nd ed.). Thousand Oaks, CA: Sage. 
Flick, U. (2014). An introduction to qualitative research (5th ed.). London, UK: Sage.

Fox, D. (2014, March/April). Observations: Ensuring quality instructional strategies. Leadership, 28-34.

Galton, M., Gray, J., \& Rudduck, J. (2003). Transfer and transition in the middle years of schooling (7-14): Continuities and discontinuities in learning (Research Report 443). Retrieved from http://www.lotc.org.uk/wp-content/uploads/2010/12/DfES-Research-Report-RR443-20 03.pdf.

Gillham, B. (2000). Case study research methods. London, UK: Continuum.

Gillies, J., \& Jester Quijada, J. (2008). Opportunity to learn: A bigh impact strategy for improving educational outcomes in developing countries (Working paper). Washington, DC: EQUIP2.

Glass, G. V., Cahen, L. S., Lee Smith, M., \& Filby, N. N. (1982). School class size: Research and policy. London, UK: Sage.

Gomm, R., Hammersley, M., \& Foster, P. (Eds.). (2000). Case study method. London, UK: Sage.

González, A. (2009). On alternative and additional certifications in English language teaching: The case of Colombian EFL teachers' professional development. Íkala, Revista de Lenguaje y Cultura, 14(22), 183-209.

González Robles, R. O., Vivaldo Lima, J., Castillo Morales, A. (2004). Competencia lingüistica en inglés de estudiantes de primer ingreso a instituciones de educación superior [Linguistic competence in the English language of students entering university for the first time]. Mexico DF, MX: ANUIES.

Goodson, I. (1988). The making of curriculum: Collected essays (2nd ed.). London, UK: The Falmer Press.

Haque, E., \& Cray, E. (2007). Constraining teachers: Adult ESL settlement language training policy and implementation. TESOL Quarterly, 41(3), 634-642. http://dx.doi.org/10.1002/ j.1545-7249.2007.tb00096.x.

Hodder, I. (2000). The interpretation of documents and material culture. In N. K. Denzin \& Y. S. Lincoln (Eds.), Handbook of qualitative research (2nd ed., pp. 703-715). Thousand Oaks, CA: Sage.

Li, D. F. (1998). It's always more difficult than you plan and imagine: Teachers' perceived difficulties in introducing the communicative approach in South Korea. TESOL Quarterly, 32(4), 677-703. http://dx.doi.org/10.2307/3588000.

Merriam, S. B. (2009). Qualitative research: A guide to design and implementation. San Francisco, CA: Jossey-Bass.

Nunan, D. (2003). The impact of English as a global language on educational policies and practices in the Asia-Pacific region. TESOL Quarterly, 37(4), 589-613. http://dx.doi.org/10.2307/ 3588214.

Opfer, V. D., \& Pedder, D. (2011). Conceptualizing teacher professional learning. Review of Educational Research, 81(3), 376-407. http://dx.doi.org/10.3102/0034654311413609.

Patton, M. Q. (2002). Qualitative research and evaluation methods (3rd ed.). London, UK: Sage. 
Peng, N. (2007). Strategies in teaching English to large classes in the universities. US-China Education Review, 4(1), 66-69.

Prapaisit de Segovia, L., \& Hardison, D. M. (2009). Implementing education reform: EFL teachers' perspectives. ELT Journal, 63(2), 154-162. http://dx.doi.org/10.1093/elt/ccn024.

Prior, L. (2003). Using documents in social research. London, UK: Sage.

Richards, K. (2003). Qualitative inquiry in TESOL. London, UK: Palgrave. http://dx.doi.org/ 10.1057/9780230505056.

Rubin, H. J., \& Rubin, I. S. (1995). Qualitative interviewing: The art of hearing data. London, UK: Sage.

Sarwar, Z. (2001). Adapting individualization techniques for large classes. In D. R. Hall \& A. Hewings (Eds.), Innovation in English language teaching: A reader (pp. 127-136). London, UK: The Open University.

Secretaría de Educación Pública, SEP. (2006). Educación Básica. Secundaria. Lengua Extranjera. Inglés. Programas de estudio 2006. Mexico City, MX: Author. Retrieved from http:// www.curriculobasica.sep.gob.mx/pdf/pnieb/pe_ingles_2006.pdf.

Silver, R. E., \& Skuja Steele, R. (2005). Priorities in English language education policy and classroom implementation. Language Policy, 4(1), 107-128. http://dx.doi.org/10.1007/ s10993-004-6567-1.

Stake, R. E. (1995). The art of case study research. London, UK: Sage.

Stake, R. E. (2003). Case studies. In N. K. Denzin \& Y. S. Lincoln (Eds.), Strategies of qualitative inquiry (pp. 134-164). London, UK: Sage.

Van'Tassel-Baska, J., Avery, L., Struck, J., Feng, A., Bracken, B., Drummond, D., \& Stambaugh, T. (2003). The William and Mary classroom observation scales revised. Williamsburg, VA: The College of William and Mary School of Education Center for Gifted Education. Retrieved from http://education.wm.edu/centers/cfge/_documents/research/athena/cosrform.pdf

Wedell, M. (2008). Developing a capacity to make "English for Everyone" worthwhile: Reconsidering outcomes and how to start achieving them. International Journal of Educational Development, 28(6), 628-639. http://dx.doi.org/10.1016/j.ijedudev.2007.08.002.

Zappa-Hollman, S. (2007). EFL in Argentina's schools: Teachers' perspectives on policy changes and instruction. TESOL Quarterly, 41(3), 618-625. http://dx.doi.org/10.1002/ j.1545-7249.2007.tb00094.x. 
Nora M. Basurto Santos and Jolene R. Gregory Weathers

\section{The Authors}

Nora M. Basurto Santos holds a PhD in ELT and Applied Linguistics from Warwick University in England. She is a full-time researcher at the Universidad Veracruzana, Mexico, where she teachers in the undergraduate and postgraduate programs in English as Foreign Language and Applied Linguistics.

Jolene R. Gregory Weathers holds a BA in Biology/Pre-med from Colorado State University (USA). She has 15 years of classroom experience in teaching EFL in Mexico. Currently, she is studying for a Master's in Teaching English as a Foreign Language at Universidad Veracruzana (Mexico). 